\title{
Decolonization in the Former Soviet Borderlands: Politics in Search of Principles
}

\author{
Gregory W. Gleason, University of New Mexico \\ Susan J. Buck, University of North Carolina at Greensboro
}

\begin{abstract}
Marx is reputed to have said that "there is nothing so practical as a good theory." Seventy-odd years of Soviet theorizing have left little useful practical theory behind, as demonstrated by the transformations currently taking place in Russia's borderlands. As the Soviet Union crumbles, the successor states face a unique and troubling situation. For over 70 years, their administrative structures have been centralized; their economies, transportation and communications systems, and the physical infrastructure all controlled from Moscow under a coherent ideological regime. The successor states find themselves adrift ideologically and administratively, but the centralized physical infrastructure remains.
\end{abstract}

How are these states to design new administrative structures? How are they to cope with the utter failure of their theoretical principles? How may they cooperate in the use of the physical systems while establishing their political independence? Soviet administrative theory-the "scientific theory of socialism"' as it was called - has been unable to provide even the most basic guidance for the process, and western administrative theory is not equipped to address the special problems of the new states. The insights of the neo-institutionalists can provide guidelines for these urgent problems.

\section{The Failure of Soviet Administrative Science}

Throughout the 1960s and 1970s in particular, Soviet society devoted immense resources to innumerable social science institutes and bureaus that analyzed such topics as the "scientific study of society," the "scientific organization of labor," and the "optimalization of economic functioning." Yet Soviet administrative science was unable to leave any- thing in the way of a theoretical legacy. Scholars in the former Soviet lands find this disturbing, although western scholars, who rejected the conceptual underpinnings of Soviet administrative theory, are less surprised. Gripped by centrist ideology, the Soviet academies could hardly be expected to design decentralized institutions and administrative strategies.

More disturbing, however, is the realization that western scholars cannot provide useful guidelines for the organizational changes. The rapidity of the changes is partly to blame. Some of the blame may be attributed to the fact that western theoretical constructs that should have wide applicability-market theory and comparative administration, in particular-have not been developed with sufficient generality to address the scope of the changes introduced by the fall of totalitarian governments. Finally, western scholars have failed to recognize the situation as a problem of decolonization.

On a practical level, the need to define new structures is urgent. The withdrawal of centralized control from Moscow has left the new countries with interruption of commercial relations, a breakdown in communication and transportation, and an enormous environmental rectification burden. The aged Soviet physical infrastructure is incapable of supporting the competitive entrance of many industrial and agricultural sectors into the world market.

Attempts to apply market theory in the new states provide a good illustration of the difficulties.

"Privatization" and "transition to the market" are offered as the solutions to the successor states' problems. In comprehending the dynamics of these processes in the postSoviet context, analysts tend to rely upon the basic models of the privatization and decentralization processes in western contexts (Bennett 1990;
Cameron 1990; DeAlessi 1987;

Fallenbuchl and Fallenbuchl 1990; Heald 1990; Ohashi and Roth 1990; V. Ostrom 1976; Pirie 1985; Pryor 1991; Savas 1987; Schroeder 1988). Consequently, analysts speak in terms of "restoring" property rights and "returning" to the natural administrative boundaries that predated the Soviet collectivist experiment. However, the post-Soviet context is very different. In most of the newly independent states, the political and administrative borders are artificial products of the Soviet period. Private property arrangements have been disrupted for more than a century, first by Russian colonialism and then by 70 years of Soviet-style socialism. Indeed, in many areas there is no historical record at all of private property rights in water and agricultural land. In most areas, geophysical and cadastral surveys of the land do not exist and may never have existed. How can such land be privatized and deeded when there is no way to describe the property legally?

In sum, the post-Soviet countries face the intersection of profoundly theoretical questions about defining the institutions of their future-questions that would seem to require careful reflection-and the urgent necessity to act quickly. At present, the process of institutional redesign is neither theoretical reflection nor pragmatic administration. The process is being guided by politics.

\section{Decolonization Post-Soviet Style}

During the final year of the Soviet government, theoretical proposals for political reform dominated public attention. Concepts of federal reform vied with concepts of "refederalization," "confederalization," and "de- 
federalization." At the close of 1991, the leaders of 11 Soviet Socialist republics created a Commonwealth of Independent States (CIS). This new group was ambiguous from its very inception: the founding document (the Alma-Ata Declaration of December 21, 1991) declared the CIS to be "neither a government nor a supra-governmental organization." It seemed more an expression of goodwill, or perhaps the final piton before the successor states could scale an unfamiliar rock face.

Each of the successor states received diplomatic recognition from major world powers and joined the United Nations. Each of the states has actively sought cooperative assistance from international organizations such as the International Monetary Fund and the World Bank. And each of the states pledged to uphold international standards of conduct such as the principles of the Conference on Security and Cooperation in Europe (CSCE).

Yet, there is great uncertainty associated with the futures of these states. Consider only the new states of Central Asia. All of these countries were created during the Soviet period; none of these states existed as independent entities prior to 1917. All are subject to strong centrifugal ethnic, subnational, and religious pressures. All are linked by religious, cultural, and linguistic bonds to countries beyond the former Soviet borders. And all face delicate and dangerous relations with their neighbors over issues of border security, trade relations, and transboundary resources such as water. The parallels here with the decolonization of Africa earlier in the century are striking.

Decolonization was one of the most significant global political events of this century. The "decade of decolonization" began as African states were integrated into the international community. In 1956, the Sudan, Tunisia, Morocco, and the Gold Coast (Ghana) won independence. Guinea followed two years later. In 1960, the French attempt to establish a commonwealth similar to the British Commonwealth faltered. More than a dozen former colonies rapidly became independent. In all, 47 nation states emerged from the former empires.

If this decolonization process is adopted as the model for the new states of Central Asia, it is clear that some of the patterns are similar, some different. As in many decolonized areas, the national boundaries of the Central Asian states are artificial structures, adopted primarily for the convenience of the metropole, but no pre-existing national identities were associated with these states. As in many decolonizing areas, there were nationalist movements stirring, but political opposition was not the key to change, and no powerful, charismatic, heroic leaders were swept into power with a moral mandate. Like most decolonizing areas, there was a stratum of metropolitan settlers in privileged positions, but those privileges were not associated with private property and did not offer any advantages after independence. Like most cases of decolonization, the metropole had grown reliant, if not dependent, on a flow of raw materials from the colonies, but Moscow had also extended its basic physical infrastructure of communication, energy, transportation, and scientific research to these areas in such a way that both the center and the periphery were vulnerable to dislocations.

One of the most compelling examples of the dislocation of government institutions is the political fragmentation of the highly centralized water management system in the states of the former Soviet southern tier, Central Asia. ${ }^{1}$ Now that the individual Central Asian states have sovereignty over their natural resources, they find themselves at odds with one another in a way that they never experienced while they were tributary states of the USSR.

Central Asia's two main river systems, the Syr Darya and the Amu Darya, irrigate roughly $75 \%$ of Central Asia's agriculture. Each of these rivers flows through three of the five Central Asian states. ${ }^{2}$ Due to agricultural draws, the inflow to the Aral Sea from the Syr Darya and the Amu Darya rivers fell to near zero by 1982; the desiccation of the Aral Sea threatens the local economy and the ecology of the entire Aral Sea basin, and it may have hydrometeorological effects on a global scale (Micklin 1991). As long as the Central Asian irrigation system was under the control of Moscow, it continued to function without overt conflict among appropriators. With the transition to political independence, conflicts that were previously resolvable by fiat from Moscow became international transboundary conflicts.

Water management is not the only issue generating conflict between the successor states. They also find themselves arrayed antagonistically in terms of trade, security, and the allocation of other natural resources. These pressures result in greater demands on the new capitals to solve pressing problems. This tends to strengthen the "hard shell" of each of the new nation states, turning them to a dangerous form of selfreliance when most nations are moving toward interdependence.

\section{Decentralization: In Search of Institutional Equilibria}

It is clear that the centralized economy controlled by Moscow has vanished and that replacement institutions must be either salvaged from the old or created with new ideas and structures. The colonial approach used by the Soviet government did not encourage indigenous management regimes and the Soviet-style bureaucratic institutions are entrenched in the new governments of the borderlands. The successor states are eagerly embracing market solutions, although they have an imperfect understanding of markets and private property institutions. The level of decision making has moved out of Moscow and into the new capitals. The central question now is: once decentralization has started, how far should it proceed? Accepting market solutions and private property institutions as defining optimal equilibria fails to give any direction in deciding the optimal level for decision making. The search for solutions to these questions requires a return to the logical primitives of neo-classical and neo-institutional economics: market theory and hierarchy theory.

Theoretical economists have emphasized the collective action trap encountered by collectivist societies 
because of a disjunction between ownership and incentives (Coase 1937; Olson 1965; Demsetz 1967; Alchian and Demsetz 1973; Axelrod 1981). They have explored the theoretical relationships between collective management institutions and the phenomena of free-riding, shirking, opportunism, and risk-avoidance (Moe 1984; Eggertsson 1990; North 1990). Recent re-analysis of the returns from the Soviet experiment of these past seven decades has provided convincing empirical evidence for these economists' theoretical conclusions: in the Soviet Union, the attempt to transfer all categories of property into the category of "public" property led to massive problems of free-riding and opportunistic behavior and, eventually, to resource exhaustion on a scale far surpassing that of societies recognizing private property conventions (Kaminski 1992; Kornai 1992).

More recent work in the neoinstitutional tradition has led to theoretical breakthroughs regarding the complex interplay of institutional design and individual incentives (E. Ostrom 1986). Ostrom's empirical studies have documented how cooperation may emerge on a local level in some political subsystems while not in other parallel systems, without respect to the scale of the system or other external variables (E. Ostrom 1990). She argues that the specific set of decision rules (how the problems of opportunism and free riding are addressed) determine whether a particular institutional configuration leads to optimal outcomes, concluding that self-government depends not upon a specific structural configuration but rather upon the appropriateness of the rules in use. Types of durable, self-governing political organizations may vary widely; nonetheless, the use rules of the resource system are not merely important, they are the essence of the system.

Even once the dilemmas of collective action are clearly recognized and the importance of institutional design in solving the dilemmas is accepted, there is still the question of what principles should guide institutional re-designers. The boundaries of the authority of any particular level of government should be decided with respect to the contributors and bene- ficiaries of a good or service. The problem is two-fold: what level of institution most completely captures the maximum number of providers and beneficiaries, and what level of institution is most efficient in the administration of the provision of goods and services? Two principles guide the definition of these groups: fiscal equivalence and fiscal accountability.

The principle of fiscal equivalence maintains that there is a need for a governmental institution (agency, body, committee, commission, collective, boss, and so on) for every collective good with a unique boundary, so that there can be a match between those who receive the benefits of a collective good and those who pay for it (Olson 1969). For example, the Central Asian irrigation systems benefit cultivators in all of the new states; the principle of fiscal equivalence suggests that the institution that governs the allocation of irrigation water should be regional and transnational. Such an institution would be able to monitor water use throughout the river basins and could assess fees appropriately, without primary regard for the nationality of the users (Buck and Gleason 1993). Any lower level of institution would exclude some beneficiaries from the management institution, leading to some of the compliance problems of commitment, monitoring, sanctioning, and conflict resolution identified by Ostrom (E. Ostrom 1990).

The second postulate, fiscal accountability, states that only those who pay for a good should benefit from it and only those who benefit should be required to pay: free riding and spillovers are unacceptable on principled grounds as well as economic ones. Adherence to fiscal accountability may be relaxed in favor of redistributive policies, but even when it is suspended, benefits should be proportional to payments. Thus institutions must be established at the level that captures jurisdiction over the costs of provision and the reception of benefits. In Central Asia, for example, the benefits of irrigation have widespread economic implications throughout the economies of all the new states. Management institutions constructed at a purely national level would not adjust to the costs and benefits in neighboring economies. The costs of misapplication of pesticides would be borne by downstream water users, and the rewards for water conservation would be dispersed to other sectors of the economy, for example, by increasing the amount of water available for new housing construction or industrial development. With a regional management institution, these costs and rewards could be adjusted across borders.

Clearly, these two principles are complementary. By defining a unique boundary for the good or service, the principle of fiscal accountability sets the parameters of the management institution as small and as low in the hierarchy as possible. By directing our attention to the possible inefficiencies caused by externalities, the principle of fiscal equivalence encourages the designers to cast their institutional nets more widely. The balance between the two is a matter of judgment, but deliberate consideration of both principles fosters enhanced institutional designs.

As the public and private institutions of the post-Soviet world are reconfigured, the prominence of local politics in determining who decides what, when, and how may not necessarily be bad. Recent empirical analysis of Third World public and private interaction has offered strong arguments that local politics may determine the outlines of local government more efficiently than centrally driven campaigns (de Soto 1989). The failure of the collectivist experiment in Russia and its borderlands is a lesson of importance for theoreticians and practitioners alike. Any analyst who truly seeks to understand institutions, hierarchy, and collective forms of management cannot afford to ignore it.

\section{Notes}

\footnotetext{
*This article draws upon a larger research project on natural resource policies within the newly independent states. Support for this research was provided by grants from the National Science Foundation (\#SES-914766) and the National Council on Soviet and East European Research (\#806-13).

1. It is traditional to speak of the southern tier republics of Kyrgyzstan, Tajikistan, Turkmenistan, and Uzbekistan as the core Central Asian republics. Many sources
} 
include the southern veliatlar (formerly oblasts) of Kazakhstan in Central Asia as well. Contemporary common usage in the new ClS states, however, includes Kazakhstan as a whole in Central Asia.

2. The Amu Darya flows from Afghanistan through Tajikistan, through Uzbekistan, into Turkmenistan, back into Uzebkistan, and then into Karakalpakstan before reaching the Aral Sea. The Syr Darya flows from Kyrgyzstan and parts of China into Uzbekistan and then into Kazakhstan.

\section{References}

$\rightarrow$ Alchian, A., and H. Demsetz. 1973. "The Property Right Paradigm." Journal of Economic History 33:16-27.

Axelrod, R. 1981. The Evolution of Cooperation. New York: Basic Books.

Bennett, Robert, ed. 1990. Decentralization, Local Governments, and Markets. Oxford: Clarendon.

Buck, Susan J., and Gregory W. Gleason. 1993. "The 'Institutional Imperative': Resolving Transboundary Water Conflict in Arid Agricultural Regions of the US and CIS.." Natural Resources Journal (forthcoming in October).

de Soto, Hernando. 1989. The Other Path: The Invisible Revolution in the Third World. New York: Harper and Row.

Cameron, Rob. 1990. "Decentralization: A Framework for Analysis." Politikon 17: 39-50.

$\rightarrow$ Coase, R. H. 1937. "The Nature of the Firm." Econometrica 4:386-405.

$\rightarrow$ DeAlessi, L. 1987. "Property Rights and Privatization: Prospects for Privatization." Proceedings of the Academy of Political Science 36:24-35.

$\rightarrow$ Demsetz, Harold. 1967. "Toward a Theory of Property Rights." American Economic Review 57:347-59.

Eggertsson, Thrainn. 1990. Economic Behavtor and Institutions. New York: Cambridge University Press.

Fallenbuchl, Adam, and Zbigniew Fallenbuchl. 1990. "Privatization and Market- ization in Poland." Studies in Comparative Communism 23:349-54.

Heald, David. 1990. "The Relevance of Privatization to Developing Economies." Public Administration and Development 10:3-18.

Kaminski, Antoni. 1992. An Institutional Theory of Communist Regimes: Design, Function, and Breakdown. San Francisco: Institute for Contemporary Studies Press.

Kornai, Janos. 1992. The Socialist State: The Political Economy of Communism. Princeton: Princeton University Press.

Micklin, Philip P. 1991. The Water Management Crisis in Soviet Central Asia. The Carl Beck Papers No. 905. University of Pittsburgh Center for Russian and East European Studies.

$\rightarrow$ Moe, Terry. 1984. "The New Economics of Organization." A merican Journal of Political Science 28:739-77.

North, Donglass C. 1990 . Institutions, Institutional Change and Economic Performance. New York: Cambridge University Press.

Ohashi, T. M., and T. P. Roth. 1980. Privatization Theory and Practice. Vancouver, BC: Fraser Institute.

Olson, Mancur. 1965. The Logic of Collective Action. Cambridge, MA: Harvard University Press.

$\rightarrow$ Olson, Mancur. 1969. "The Principles of 'Fiscal Equivalence': The Division of Responsibilities Among Different Levels of Government." American Economic Review 59: 479-87.

Ostrom, Elinor. 1990. Governing the Commons: The Evolution of Institutions for Collective Action. Cambridge: Cambridge University Press.

Ostrom, Elinor. 1986. "An Agenda for the Study of Institutions." Public Choice 48: 3-25.

$\rightarrow$ Ostrom, Vincent. 1976. “The Contemporary Debate over Centralization and Decentralization." Publius 6:21-32.

Pirie, Madsen. 1985. Dismantling the State: The Theory and Practice of Privatization. Dallas: National Center for Policy Analysis.

Pryor, Frederic L. 1991. "When Is Collec- tivization Reversible?" Studies in Comparative Communism 24:3-24.

Savas, Emmanuel S. 1987. Privatization: The Key to Better Government. Chatham, NJ: Chatham House Publishers.

Schroeder, Gertrude E. 1988. "Property Rights Issues in Economic Reforms in Socialist Countries." Studies in Comparative Communism 21:175-88.

\section{About the Authors}

\section{Gregory W. Gleason}

Gregory W.

Gleason is an associate professor of political science at the University of New Mexico. He has written extensively on policy issues in Central Asia. He is the author of Federalism

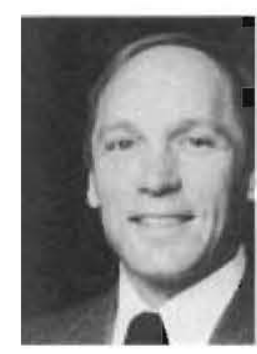
and Nationalism: The Struggle for Republican Rights in the USSR (Westview 1990) and Central Asian States: Common Sovereignty in Kazakhstan, Kyrgyzstan, Tajikistan, Turkmenistan and Uzbekistan (Westview, forthcoming).

\section{Susan J. Buck}

Susan J. Buck is an associate professor of political science at the University of North Carolina at Greensboro, specializing in environmental policy and law. Her research is focused on management of common pool resource systems. She is the author of Understanding Environmental Administration and Law (Island 1991) and The Global Commons: Their Legal and Political History (University of South Carolina Press, forthcoming). 